\title{
Potential For Agricultural Biomass Production for Energy Purposes in Poland: a Review
}

\author{
Rafał Baum', Karol Wajszczuk¹, Benedykt Pepliński \& Jacek Wawrzynowicz ${ }^{1}$
}

\begin{abstract}
This article reviews the production capacity of Polish agriculture with respect to biomass used for energy production. The forecast production potential of agricultural biomass in Poland in 2020 includes three key areas: the expected consumption of renewable energy according to energy type, the energy potential of agriculture and barriers to the use of biomass. Studies have shown that in Poland, total energy consumption will significantly increase (over 10\% by 2020). Growth of demand for renewable energy will primarily result from strong growth of demand for transport biofuels and electricity. In 2020, approximately $80 \%$ of final energy from renewable sources will come from biomass. More than three-quarters of the biomass will be generated from agriculture. In Poland, crops from 1.0 to 4.3 million ha can be used for energy production. The study shows changes in the structure of biomass use, and the analysis confirms the declining share of biomass for heat production and the increasing share of biomass for electricity and biofuels. The main obstacles to the continued use of agricultural biomass are a lack of local markets for biomass energy and poor financial support for energy crop production.
\end{abstract}

KEY WORDS: biomass, biomass production, agricultural biomass, energy crops, biofuels

JEL Classification: Q16, Q41, Q42, Q47

${ }^{1}$ Poznań University of Life Sciences, Poland

\section{Introduction}

The increasing importance of climate change and the need for environmental protection occasion new opportunities for cooperation between researchers and policy-makers. Efforts are being made worldwide, at various levels and on different scales, to integrate actions undertaken by scientists and other interested parties (Falkenmark, Gottschalk, Lundqvist \& Wouters, 2004; Holmes \& Clark, 2008; Totlandsdal, Fudge, Sanderson, van Bree \& Brunekreef, 2007). A positive example of such activity is provided, e.g., by the

-

Correspondence concerning this article should be addressed to: Rafał Baum, Poznan University of Life Sciences, 28 Wojska Polskiego Str., 60-637 Poznań, Poland, e-mail: baum@up.poznan.pl reports of the Intergovernmental Panel on Climate Change (IPCC) established in 1988. Dialogue and mutual understanding regarding problems faced by humanity constitute a huge challenge. Political considerations and the competing interests of individual countries frequently hinder the realization of global ecological aims, as exemplified by the fiasco of the Copenhagen Climate Change Conference in 2009 (Tollefson, 2009) ${ }^{1}$.

The European Union (EU) is a leader in the adoption of eco-friendly solutions, establishing highly ambitious objectives to be reached by the year 2020. In 2008, the European Parliament passed a package of resolutions referred to as the climate package (the socalled " $3 \times 20$ "). The aim of the package was to launch, 
within the EU, a "green revolution" in industry and power generation, i.e., a transition from high-emission coal to renewable energy sources and energy conservation. In the general opinion, the adopted package achieves a balance between environmental concerns and the interests of the industrial sector.

The assumed objectives adopted by the EU have resulted in increased interest in the cultivation of energy crops. Efforts undertaken by scientists aimed at systematizing information on energy crop cultivation are evident. Efficient practice requires guidelines concerning the utilization of agricultural biomass for energy purposes and optimal production (both quantitative and qualitative). Introduction of the above-mentioned solutions is complex. Production of energy biomass will provide farmers with new prospects and possibilities to diversify agricultural activity. Some of these crops may compete for land and other resources with traditional crops, while other crops may be grown on marginal lands or even ecologically degraded areas and thus have a positive effect on the environment (Zegada-Lizarazu et al., 2010).

In view of the circumstances described above, there has been growing interest in studies that present future energy scenarios. In these studies, energy demand (in various forms) and available energy resources (nonrenewable and renewable) are estimated. Then, the energy balance, i.e., a comparison of energy supply and demand (Sørensen, 2008), is assessed.

\section{Aim and methodology of the study}

The circumstances described above indicate the need for analyses of the potential of Polish agriculture to produce biomass for energy production. The primary aim of this paper is to present a forecast of the production potential of agricultural biomass in Poland in the year 2020 .

The detailed scope of the study will include the following factors:

- forecasted consumption of renewable energy in terms of energy types (electrical energy, heat, automotive biofuels),

- energy potential of agriculture (sources of agricultural biomass, utilization structure of agricultural biomass, the volume of production of solid biomass, biogas and biofuels, cultivation area of energy crops), and

- barriers to the utilization of biomass.
The study is a theoretical review that takes a heuristic approach. The presented forecast is a fragment of broader analyses conducted within the framework of a research project ${ }^{2}$.

\section{The macroeconomic context}

In the above-mentioned EU climate and energy package (December 17, 2008), it was assumed that by 2020 , the EU member countries would realize the following objectives:

- reduction of $\mathrm{CO} 2$ emission by $20 \%$ compared with 1990 ,

- increased consumption in the EU of energy from renewable sources from 8.5 to $20 \%$ of energy needs,

- an increase in energy efficiency of $20 \%$.

In Poland, in November 2009, a document entitled "Energy policy in Poland by the year 2030" was adopted by the Council of Ministers (Ministerstwo Gospodarki, 2009). It presents the government's strategy and proposes means of meeting the most important challenges facing the Polish power industry. The primary objective of energy policy in terms of the development and utilization of renewable energy sources is to increase the proportion of renewables in the total consumption of energy by at least $15 \%$ by 2020 and to further increase this index in the following years. Moreover, it was assumed that in 2020, a $10 \%$ share of biofuels will be achieved in the automotive fuels market and that the utilization of second-generation biofuels will be increased.

Poland has considerable renewable energy resources (it is estimated that the technical potential of renewables exceeds that of Denmark and Sweden) that may be used to meet almost $50 \%$ of national energy demand. Nevertheless, of the total energy balance in 2010, energy from renewable sources amounted to approximately $9 \%$ of final energy consumption. Numerous forecasts conclude [e.g., the Polish Ministry of Economy (Ministerstwo Gospodarki, 2009) or the Institute for Renewable Energy (IEO, 2010)] that in 2020 a vast majority of final energy from renewable energy sources will need to be produced from biomass, particularly agricultural biomass.

Poland is perceived, within the EU, as a country with a high potential for biomass production for energy purposes. The results of analyses and estimates prepared by some specialists indicate that, in Poland, 
Table 1. An increase in demand for final energy in individual sectors of the economy in Poland by 2020 (Minister Gospodarki, 2010)

\begin{tabular}{lllll}
\hline Specification & $\mathbf{2 0 0 6}$ [Mtoe] $^{*}$ & $\mathbf{2 0 1 0}$ [Mtoe] & $\mathbf{2 0 1 5}$ [Mtoe] & $\mathbf{2 0 2 0}$ [Mtoe] \\
\hline Industry & 20.9 & 18.2 & 19.0 & 20.9 \\
Transportation & 14.2 & 15.5 & 16.5 & 18.7 \\
Agriculture & 4.4 & 5.1 & 4.9 & 5.0 \\
Services & 6.7 & 6.6 & 7.7 & 8.8 \\
Households & 19.3 & 19.0 & 19.1 & 19.4 \\
TOTAL & $\mathbf{6 5 . 5}$ & $\mathbf{6 4 . 4}$ & $\mathbf{6 7 . 3}$ & $\mathbf{7 2 . 7}$ \\
\hline
\end{tabular}

Note

* The ton of oil equivalent (toe) is a unit of energy: the amount of energy released by burning one ton of crude oil, approximately 42 GJ. Mtoe - megatoe (one million toe).

Table 2. Demand for final energy by 2020 in terms of individual carriers (Minister Gospodarki, 2010)

\begin{tabular}{lllll}
\hline Specification & $\mathbf{2 0 0 6}$ [Mtoe] & $\mathbf{2 0 1 0}$ [Mtoe] & $\mathbf{2 0 1 5}$ [Mtoe] & $\mathbf{2 0 2 0}$ [Mtoe] \\
\hline Coal & 12.3 & 10.9 & 10.1 & 10.3 \\
Oil products & 21.9 & 22.4 & 23.1 & 24.3 \\
Natural gas & 10.0 & 9.5 & 10.3 & 11.1 \\
Renewable energy & 4.2 & 4.6 & 5.0 & 5.9 \\
Electric energy & 9.5 & 9.0 & 9.9 & 11.2 \\
Network heat & 7.0 & 7.4 & 8.2 & 9.1 \\
Other fuels & 0.6 & 0.5 & 0.6 & 0.8 \\
TOTAL & $\mathbf{6 5 . 5}$ & $\mathbf{6 4 . 4}$ & $\mathbf{6 7 . 3}$ & $\mathbf{7 2 . 7}$ \\
\hline
\end{tabular}

between 1.0 and 4.3 million ha AUA may be allocated to energy crop production (Kuś \& Faber, 2009; van Velthuizen, 2003; Wiesenthal, Mourelatou, Petersen \& Taylor, 2006).

\section{Changes in energy demand}

In accordance with the assumptions of "Energy policy of Poland by the year 2030," the forecasted increase in the consumption of final energy in Poland by the year 2020 (in comparison with 2006) will be $11 \%$, and the biggest component of this increase (31.7\%) will be in the transport sector. In the other sectors, the increase will amount to $31.3 \%$ in services, $13.6 \%$ in agriculture and $0.5 \%$ in households. Energy consumption in industry will not change (Table 1).
Analysis of data in terms of energy carriers (Table 2) shows that by 2020 , the consumption of coal will increase. The values of other energy carriers will also increase: crude oil products and natural gas by $11 \%$, renewable energy by $40.5 \%$, and electrical energy by $17.9 \%$. A $30 \%$ increase in the consumption of network heat and a $33 \%$ increase in the consumption of the other fuels are also forecast.

Given the aims of this paper, it is necessary to specify the forecast for the increase in the consumption of renewable energy in terms of its individual energy types. In accordance with the assumptions of the Ministry of Economy, the following division was applied: electrical energy (a 7-fold increase in demand by 2020 compared with 2006), heat (a 45\% increase) and automotive bio- 
Table 3. Gross final energy demand* with renewable energy sources in terms of individual energy types (Minister Gospodarki, 2010)

\begin{tabular}{|c|c|c|c|c|}
\hline Specification & 2006 [ktoe] $^{* *}$ & 2010 [ktoe] & 2015 [ktoe] & 2020 [ktoe] \\
\hline Electrical energy: & 370.6 & 715.0 & 1516.1 & 2686. \\
\hline Solid biomass & 159.2 & 298.5 & 503.2 & 892.3 \\
\hline Biogas & 13.8 & 31.4 & 140.7 & 344.5 \\
\hline Wind & 22.0 & 174.0 & 631.9 & 1178.4 \\
\hline Water & 175.6 & 211.0 & 240.3 & 271.4 \\
\hline Photovoltaics & 0.0 & 0.0 & 0.0 & 0.1 \\
\hline Heat: & 4312.7 & 4481.7 & 5046.3 & 6255.9 \\
\hline Solid biomass & 4249.8 & 4315.1 & 4595.7 & 5405.9 \\
\hline Biogas & 27.1 & 72.2 & 256.5 & 503.1 \\
\hline Geothermal & 32.2 & 80.1 & 147.5 & 221.5 \\
\hline Solar energy & 3.6 & 14.2 & 46.7 & 125.4 \\
\hline Automotive biofuels: & 96.9 & 549.0 & 884.1 & 1444.1 \\
\hline Carbohydrate-starch bioethanol & 61.1 & 150.7 & 247.6 & 425.2 \\
\hline Rapeseed biodiesel & 35.8 & 398.3 & 636.5 & 696.8 \\
\hline 2nd generation bioethanol & 0.0 & 0.0 & 0.0 & 210.0 \\
\hline 2nd generation biodiesel & 0.0 & 0.0 & 0.0 & 112.1 \\
\hline Biohydrogen & 0.0 & 0.0 & 0.0 & 0.0 \\
\hline TOTAL gross final energy from renewable energy sources & 4780.2 & 5745.7 & 7446.5 & 10386.6 \\
\hline Gross final energy & 61815.0 & 61316.0 & 63979.0 & 69203.0 \\
\hline Proportion of energy from renewable energy sources [\%] & 7.7 & 9.4 & 11.6 & 15.0 \\
\hline
\end{tabular}

Notes

* Gross final energy was defined in the Directive on renewable energy sources as final consumption of energy carriers for energy needs + losses of electrical energy and heat in transmission and distribution + own consumption of electrical energy for the production of electrical energy + own consumption of heat for the production of heat.

** ktoe - kilotoe (one thousand tons of oil equivalent)

fuels (a 15-fold increase). In the years 2006 - 2020, the largest relative increases will be observed in wind power (a 54-fold increase) and in solar heat (a 35-fold increase) - see Table 3. The initiation of photovoltaic energy production, as well as second-generation bioethanol, second-generation biodiesel and biohydrogen, are planned for as late as 2020 - 2025.

Advances in wind power, production of biogas and solid biomass as well as automotive biofuels will play a decisive role in Poland (in terms of the achievement of the $15 \%$ share of renewable energy in the gross final energy structure in 2020). In 2020, these four areas together will most likely account for approximately $94 \%$ of energy consumption from all renewable resources.

\section{Development of biomass production}

The analysis of the feasibility of Poland's quantitative objective in targeting a $15 \%$ share of energy from renewable sources in 2020 was presented, e.g., by the In- 
Table 4. Assumed volumes of final energy from renewable energy sources required for realization of the $15 \%$ target in 2020 (IEO, 2010)

\begin{tabular}{lll}
\hline RES type & Final energy in 2020 [PJ] & Percentage \\
\hline Solar energy & 16 & 3.3 \\
Geothermal energy & 12 & 2.5 \\
Biomass, including: & 382 & 78.9 \\
Energy crops & 135 & 27.9 \\
Biofuels & 59 & 12.2 \\
Biogas & 98 & 20.2 \\
Other & 90 & 18.6 \\
Hydro power & 11 & 2.3 \\
Wind power & 63 & 13.0 \\
Total RES & 484 & 100.0 \\
\hline
\end{tabular}

stitute for Renewable Energy (IEO, 2010). The authors of the study assumed that the renewable energy resources available in Poland must meet two conditions: - availability, i.e., it must be technically feasible to use them,

- economic justification, i.e., their use must satisfy a certain effect/outlay ratio.

The forecast includes the expected and most logical scenarios to reach the assumed share of renewable energy in the final energy balance. The analysis allows for the technical potential of renewable energy sources - the potential for the development of infrastructure and production technology while also accounting for resource limitations (in the case of biomass, these limitations are chiefly the cultivated area and yield). Next, the technological potential was corrected for the cost aspects of energy production, assuming that the production costs of renewable energy are strongly correlated with economic conditions. The assumptions included the absence of the possibility for biofuel and certificate trade (or a zero balance of the trade) and that none of the sources would be specially privileged in the general support system. Table 4 shows the results of the scenario of a $15 \%$ target achievement.

Analysis of the data in the table indicates that the dominant role in the production of renewable energy in the future is attributed to biomass (nearly $80 \%$ of total renewable energy production).
Biomass is viewed as the renewable energy source with the greatest resource base, the utilization of which is sufficiently inexpensive that it may become competitive with fossil fuels. It may be used in combustion processes of solid and gas biofuels or processed into liquid fuels for the production of both electrical and heat energy.

At present, solid biomass resources are associated with the utilization of excess straw and hay, wood waste, energy crops and agricultural waste. Biomass is mainly used in the production of heat energy in small and medium power facilities in scattered generation (individual furnaces and local boiler houses). In the future, a considerable role will be allocated to the production of electrical and heat energy within a single technological process, i.e., cogeneration.

The actual economic potential of energy biomass in Poland is estimated at $600 \mathrm{PJ}$, of which the greatest portion of energy may be obtained from energy crops, estimated at 287 PJ (i.e., 47.83\%). The next-highest source of energy is solid (dry) waste, with a potential estimated at $166 \mathrm{PJ}$ (i.e., 27.66\%), wet waste for biogas production, with a potential estimated at 123 PJ (i.e., 20.51\%), and forestry products, with a potential estimated at 24 PJ (i.e., 4.00\%) (Michałowska-Knap, Włodarski \& Dietrich, 2010).

Due to the limited potential utilization of fuel wood from forests, wood waste from the wood industry or 
straw from agriculture, it will be necessary to establish perennial energy crop plantations to reach the quantitative target (15\%) contained in the Directive 2009/28 EU. Increased utilization of biomass from energy crops requires the establishment of an entire system, including production, distribution and utilization of biomass. The primary factor reducing the production of biomass is the area of utilized agricultural land. In Poland, that figure is approximately 0.41 ha UAA per capita, while in the countries of the "old" EU (EU-15), this value is only 0.19 ha. For this reason, Poland has long been viewed as a country with great potential for producing biomass for energy purposes in the EU.

In terms of biomass obtained from utilized agricultural areas, we may distinguish several categories: straw, cereal grain, rape (seed and straw), hay, biomass accompanying other crops (e.g., sugar and fodder beet leaves) and biomass from special energy crop plantations.

Biomass is divided into three major categories of utilization: biomass for the production of automotive biofuels (mechanical energy production), biomass for the power industry (electrical energy production) and biomass for heat generation (thermal energy production).

\section{Agricultural biomass for the production of liquid biofuels}

Production of this group of biofuels is a priority in light of legal regulations in the EU, and agriculture should first secure the necessary amounts of raw materials. According to the National Index Objective, the share of biocomponents in automotive fuels should gradually increase from $4.6 \%$ in 2009 to $8 \%$ in 2015 and $10 \%$ in 2020 (Rozporządzenie Rady Ministrów, 2007).

Liquid biofuels obtained from biomass conversion are mainly bioethanol and biodiesel. In Poland, agriethanol is chiefly used as an additive to petrol. The best substrates for ethanol production are sugar beets, maize, potatoes, cereals and molasses. Biodiesel is a fuel produced from vegetable (chiefly rapeseed oil) or animal fats (Grochal, 2006).

With respect to the forecasted production of firstgeneration biofuels in Poland, according to the forecasts of the Ministry of Economy (Minister Gospodarki, 2010) ${ }^{3}$, in 2020, the demand for raw materials for the production of automotive biofuels will be

- total demand for cereals for energy purposes: $1,915,050$ tons $(638,350 \mathrm{ha})$, utilization of molasses for the production of bioethanol: 165,693 tons,

demand for rape for energy purposes: 4,494,550 tons $(1,361,985$ ha $)$.

A lower demand for rapeseed for the production of esters is forecast by IUNG (Kuś \& Faber, 2007). When limiting factors are taken into account, the potential area cropped for rape for fuel substitution in Poland has been estimated at 1.0 - 1.1 million ha in 2020 (with an increase in yield to $3.2 \mathrm{t} / \mathrm{ha}$ ).

Ethyl alcohol may be produced from cereal grain (mainly maize), potatoes and sugar beets. However, under current economic conditions, the production of alcohol from beets or potatoes is more costly than from cereals. Thus, it may be assumed that bioethanol will be produced from cereals, primarily maize. It is calculated by Kuś and Faber (2009) that, in 2020, approximately 2.5 million tons of grain will need to be processed into bioethanol. It is difficult to estimate the area required for the production of such amounts of grain due to the possibility of growing different cereal species. Additionally, it is difficult to assess the amount of imported cheaper bioethanol produced from sugar cane. However, for simplicity, it was assumed that only bioethanol produced in Poland will be used and that the yield of grain will be $4 \mathrm{t} / \mathrm{ha}$. Then, the area cropped for cereals processed into bioethanol should increase from approximately 280 thousand ha in 2009 to 600 thousand ha in 2020. In this case, there is no significant difference between this model's prediction and the forecast of the Ministry of Economy.

\section{Agricultural biomass for the production of heat and electrical energy}

Of all the types of unprocessed biomass, straw and energy crop biomass are most suitable for utilization in large commercial heat and power generation plants. The amount of straw that may be collected for the needs of electrical power generation is shown in Fig. 1.

Of all cereal and other plant species, the power industry primarily uses straw. Rye, wheat, rape, buckwheat, fava bean, sunflower straw and corncobs are particularly valuable. In Poland, straw production is estimated at $25-28$ million tons annually, of which approximately 4.9 million tons of cereal and rape straw may be used for energy purposes, according to mod- 




Figure 1. Potential straw production for energy in individual provinces of Poland [thousands of ton/provinces]* (Krawiec, 2010) Note

* Explanation: in 12 provinces (marked in gray on the map) there is a surplus of straw that can be exploited for energy purposes.

est forecasts. This amount meets the demand of animal production for feed and bedding as well as for straw ploughed under to maintain a sustainable balance of organic substance ${ }^{4}$.

When estimating the amount of straw that may be used for alternative purposes, it must be emphasized that in regions with fragmented agrarian structures, the transport of straw will not be profitable. In contrast, large amounts of straw for energy purposes may be collected in regions with a preponderance of large farms - with potentially more than $90 \%$ UAA allocated to cereals and rape and with limited animal production. However, on such farms, approximately $50 \%$ of straw should be ploughed under to provide sustainable organic soil matter and the rest may be allocated for energy purposes. It must be emphasized that this excess is highly varied regionally: it is greatest in the Wielkopolskie province and lowest in the Podlaskie and Małopolskie provinces.

Straw for energy purposes may be used as a solid fuel or as a substrate for the production of biogas.
From excess straw, alternatively used for energy generation in the gasification process, approximately 1.0 - 1.5 billion $\mathrm{m}^{3}$ biogas may be produced (Minister Gospodarki, 2010).

To forecast the potential generation of biogas in Poland, we must consider several sources of this raw material. Biogas may be obtained from landfill, sewage sludge, industrial sewage or waste and from agri-food processing (from distilleries, yeast production, fruit pulp, and abattoir waste). It may also be obtained from waste and biomass from agriculture: from animal excreta (liquid manure, animal slurry, manure), organic waste-grasses, straw, beet leaves, potato vines, maize, harvest residue or energy crops (such as catch crops, cereals and grasses) (Grochal, 2006).

In 2007, Poland accounted for over $1 \%$ of European biogas production, amounting to 62.6 ktoe. In the years 2006 - 2008, an increase was observed in the generation of biogas (from 2613 TJ, in 2006, to 5515 TJ, in 2008). Since 2006, the production of biomethane in Poland has been based mainly on biogas from sew- 
age sludge. In 2008, $72 \%$ of the produced biogas came from this source. At the end of 2009, 125 biogas generation plants were installed in Poland (including biogas generation plants from sewage treatment plants - 46; landfill biogas generation plants - 73; agricultural biogas generation plants -6 ). The rated power of all biogas generation plants is approximately $70 \mathrm{MW}$, including 7 MW from agricultural biogas generation plants.

The target energy production potential of agriculture makes it possible to obtain raw materials required for the generation of approximately 5 billion $\mathrm{m}^{3}$ of biogas annually. This potential may secure the raw material needs of approximately 2,000 agricultural biogas generation plants. At the same time, these raw materials crops, including those defined as energy crops, can be used as a substrate for biogas generation plants over an area of approximately 700 thousand ha. The realistically available raw material potential for the production of biogas, contained in the by-products of agriculture and the production waste of the agri-food industry, is approximately 1.7 billion $\mathrm{m}^{3}$ of biogas annually. In Poland, approximately 14 billion $\mathrm{m}^{3}$ of natural gas are utilized annually, including consumption of approximately 500 million $\mathrm{m}^{3}$ of gas by individual consumers in rural areas. The estimated amount of biogas after refining may cover approximately $10 \%$ of the national demand for gas or completely meet the demand of consumers from rural areas. Additionally, it could supply 125 thousand MWh of electrical energy and 200 thousand MWh of heat energy (Minister Gospodarki, 2010).

Cereal grain is also a valuable fuel. For years, it has been used for heating purposes in Scandinavia. For example, in Sweden, from which this technology was imported to Poland, hundreds of grain combustion installations are in operation. Grain combustion is also common in Canada and the USA. Studies conducted at the University of Minnesota show that heating with maize kernels is economically competitive compared to heating with oil, gas or electricity. Oats are particularly recommended for combustion as they are readily combustible (moisture content 10 - $13 \%$, calorific value $18.5 \mathrm{MJ} / \mathrm{kg}$, ash $0.6 \%$ ). Transport and storage of oats is easier than transport and storage of other types of biomass, e.g., wood or straw. Three tons of oats are needed for the production of 10 thousand $\mathrm{kW}$ of heat energy, which corresponds to
$1 \mathrm{~m}^{3}(1,000 \mathrm{l})$ of fuel oil. In the heating season, $6-7$ tons of grain are used. Oats harvested from 2 ha are sufficient to heat one farm. Similarly, the production of biomass on meadows not used for animal production is underestimated. The mean yield of dry hay matter from Polish meadows is approximately $15 \mathrm{t} /$ ha. Among native grasses, the best-yielding species is common reed, with yields of $2-30 \mathrm{t} / \mathrm{ha}$. Assuming that the calorific value of $1 \mathrm{~kg}$ of coal is $25 \mathrm{MJ}$ and that $1 \mathrm{~kg}$ of grass biomass provides $15 \mathrm{MJ}$, even at low grass yields of $5 \mathrm{t} / \mathrm{ha}$, we may obtain the equivalent of a purchase of $3 \mathrm{t}$ of coal. In contrast, the harvest of biomass at $20 \mathrm{t} /$ ha produces an equivalent of $12 \mathrm{t}$ of coal (Krawiec, 2010).

A noteworthy charge fuel for boilers is found in the biomass of special plants, which should be classified as high-energy crops. High-energy crops are plant species, the growing of which within one vegetation cycle provides an amount of energy potential above average. Such plants include willows from the genus Salix viminalis var. Gigantea, Virginia fanpetals Sida hermaphrodita Rusby, Japanese rose Rosa muli flora, Jerusalem artichoke Helianthus tuberosus L., poplars Populus L., and common locust Robinia pseudoacacia L. These high-energy crops also include the so-called energy grasses, which mainly come from the genus Miscanthus and include giant miscanthus Miscanthus gigantea, Miscanthus sacchariflorus, Spartina pectinata and Andropogon gerardi.

In Poland, plantations of only two of the abovementioned plants are of practical importance: willows and miscanthus. Biomass from grasses of the genus Miscanthus is used in heating boilers in small heat-generation facilities. High contents of silica compounds exclude its use as fuel for large boilers in heat and power generation plants. High yields, easy harvest and relatively high profitability are arguments for the development of plantations of this plant in the near future to yield biomass to be used in small-capacity boilers. Willow from special plantations is the most suitable biomass for the high-capacity power industry. At present (2010), willow plantations occupy an area of approximately 10 - 12 thousand hectares (MajewskaSawka, 2009).

It is estimated that in 2020, the total demand for biomass will be approximately 10 million tons (Grzybek, 2008). In view of the above observations on per- 
Table 5. Changes in the structure of biomass use (Minister Gospodarki, 2010)

\begin{tabular}{lllll}
\hline Use of biomass & $\mathbf{2 0 0 6}[\%]$ & $\mathbf{2 0 1 0}[\%]$ & $\mathbf{2 0 2 0}[\%]$ & $\mathbf{2 0 3 0}[\%]$ \\
\hline Electricity & 3.8 & 6.3 & 14.9 & 16.1 \\
Heat & 94.0 & 83.3 & 71.4 & 72.3 \\
Biofuels & 2.2 & 10.4 & 15.7 & 11.6 \\
\hline
\end{tabular}

manent energy crop plantations, it would be necessary to produce approximately 5 million tons of biomass annually. At the assumed yield of $9-10 \mathrm{t} \cdot \mathrm{ha}^{-1}$ of dry mass, the area of such plantations should cover over 500 thousand ha.

\section{Discussion}

To summarize these considerations regarding the production of energy from renewable sources, special emphasis must be placed on the production of agricultural biomass. As seen in the data provided above, Poland has a high biomass production potential in comparison with fellow EU member states as well as with countries outside the EU. This production results, most importantly, from high per capita utilization of agricultural areas followed by a relatively well-developed agricultural sector, a large amount of woodlands and a well-developed agri-food industry. A weakness of such an extensive market for biomass is the poor organization of the biomass market, characterized by high diversity, limited stability and relatively low market prices (particularly for by-products).

However energy economy regulations of the EU impose on Poland an obligation to include renewables on a greater scale in the energy balance. To achieve this goal, we must focus on the structure of biomass use in energy management.

As noted in studies and analyses, the structure of biomass use in Poland has been changing (Table 5). In 10 - 20 years, the share of biomass in heat production will most likely decrease (by over 20\%). The share of biomass allocated to the production of electricity and biofuels will therefore increase several times over.

\section{Barriers to biomass use}

According to the Polish Chamber of Commerce for Renewable Energy ${ }^{5}$ (PIGEO), the most important obstacles to more extensive use of biomass include
1. the lack of local energy biomass markets.

2. poor structure of the subsidy system for energy crop cultivation.

3. the lack of distinct limitations for co-combustion of biomass in high-capacity coal boilers.

4. the lack of a simple support system for the common application of individual biomass energy installations (small boiler houses and heat and power generation plants).

5. the lack of an emission control system for low-capacity energy installations (e.g., for biomass below $1 \mathrm{MW})$.

6. the lack of any standards regarding biomass fuels and discrepancies in the classification of wastes that could be potential sources of biomass for energy purposes and the lack of requirements regarding equipment and its potential thermal conversion.

7. Moreover, in terms of the use of biomass and agricultural waste for the production of biogas, PIGEO notes the following factors:

- The absence of waste from biogas production in the resolution on the list of waste types that may be supplied to physical persons. The energy use of biogas is profitable only in combination with the function of waste management for waste from animal, plant and food production.

- A poor subsidy support system for biogas investments. Such investments, meeting two ecological purposes (management and utilization of renewables), should be treated as a higher priority in the funding of ecological initiatives.

- The lack of a clear-cut interpretation of regulations regarding renewable origin certification for energy generated in high-performance cogeneration.

It must be remembered that Poland has a limited, though highly utilized, agricultural area that has been systematically decreasing. In just the years 1990 2008, UAA dropped by over 2.5 million ha. This de- 
crease was mainly caused by the transfer of UAA to non-agricultural uses. In the cited period, the area of cropped arable land dropped even further-by 2.6 million ha. A considerable reduction was found in the area cropped for potatoes, fodder crops and sugar beets (the area cropped for cereals remains stable; only the area devoted to rape cultivation has increased). Despite the large area of cereal cultivation, in the last decade, Poland has been a net importer (on average approximately 0.9 million $\mathrm{t}$ of grain annually). The rapid development of an engineering infrastructure in Poland (particularly roads) and growth of the housing sector in rural areas are predicted to further reduce UAA. Within the next 20 years, agriculture is expected to lose up to 1 million ha UAA to other land uses. Additionally, the transfer of large areas of high-quality land, classified as soil classes I-III, has caused adverse effects in recent years (Kuś \& Faber, 2009).

\section{Concluding remarks}

The most important conclusions concerning forecasts of the utilization of energy, the share of renewable sources in the supply of energy and the production potential of agricultural biomass by 2020 , are the following:

1. By 2020, a considerable increase in final energy consumption (over 10\%) is expected in Poland. This increase will be mainly a consequence of the development of the transport and service sectors. Except for coal, the consumption of all energy carriers will increase-most significantly, renewable energy (>40\%).

2. The increase in total demand for renewable energy will result, most significantly, from increased demand for automotive biofuels (an increase of $1500 \%)$ and electrical energy (700\%).

3. To meet the quantitative objective for Poland, i.e., a $15 \%$ share of energy from renewable sources in the final energy balance in 2020, approximately $80 \%$ of final energy from renewable energy sources (382 PJ) will be derived from biomass. Over $3 / 4$ of this biomass will be of agricultural origin.

4. The economic potential of biomass is estimated at 600 PJ, of which the greatest amount of energy may be obtained from energy crops (47.83\%), followed by solid (dry) waste at $27.66 \%$, while wet waste for the production of biogas ranks third at $20.51 \%$. The share of forestry products is estimated at only $4.00 \%$.
5. Poland has approximately 0.41 ha UAA per capita, while in the old EU, this value is only 0.19 ha. Therefore, Poland may obtain a very large share of the total production of biomass for energy purposes in the EU. In the opinion of foreign authors, Poland may allocate $1.0-4.3$ million ha to the production of energy crops by 2020.

6. In Poland, straw production is estimated at $25-28$ million tons, of which approximately 4.9 million tons of cereal and rape straw may be allocated to energy production (the greatest amount, over 1 million, in the Wielkopolska region). Straw for energy purposes may be used as a solid fuel or as a substrate for the generation of biogas.

7. Realistically, the available raw material potential for the production of biogas contained in byproducts of agriculture and agri-food industry waste amounts to approximately 1.7 billion $\mathrm{m}^{3}$ of biogas annually. The estimated amount of biogas after refining may cover approximately $10 \%$ of the gas demand of Poland or fully meet the demand of consumers from rural areas.

8. As a result of various investigations, the structure of biomass use has been changing. The share of biomass in the production of heat has decreased, while the share of biomass in the production of electrical energy and biofuels has increased. As of 2020, this structure will have shifted as follows: $14.9 \%$ electrical energy, $71.4 \%$ heat, $15.7 \%$ biofuels.

9. The most important obstacles to further use of agricultural biomass include a lack of local energy biomass markets and a poorly structured system of subsidies for energy crops. With decreasing UAA in Poland, the issue of food safety will become increasingly important and agricultural production for energy purposes may effectively compete with food production for soil and water. Such a development would have serious and adverse consequences.

\section{References}

Abelson, P. H. (1988). Science Advice to the Government. Science, 239(4844), 1077.

Falkenmark, M., Gottschalk, L., Lundqvist, J., \& Wouters, P. (2004). Towards integrated catchment management: increasing the dialogue between scientists, policymakers and stakeholders. International Journal of Water Resources Development, 20(3), 297-309. 
Grochal, W. (2006). Odnawialne źródła energii przyszłość rynku energetycznego - $w$ Polsce i $w$ regionie świętokrzyskim [Renewable energy sources future of the energy market - in Poland and in the Swiętokrzyskie region]. Paper presented at conference: Biogaz z odpadów organicznych jako surowiec energetyczny. Świętokrzyskie Centrum Innowacji i Transferu Technologii Sp. z o.o. March 23, 2006, Kielce, Poland.

Grzybek, A. (2008). Ziemia jako czynnik warunkujący produkcję biopaliw [Land area as a factor conditioning production of the biofuels]. Problemy Inżynierii Rolniczej, 1(n. d.), 63-70.

Holmes, J., \& Clark, R. (2008). Enhancing the use of science in environmental policy-making and regulation. Environmental Science \& Policy, 11(8), 702-711.

IEO. (2010). Sposób osiagnnięcia 15\% udziału energii ze źródeł odnawialnych $w$ bilansie zużycia energii w Polsce w 2020 r. Autorska prognoza Instytutu Energetyki Odnawialnej [Way to achieve 15\% share of energy from renewable sources in energy consumption in Poland in 2020. Author's forecast of Institute for Renewable Energy]. Retrieved from http:// www.preda.pl/pliki/Dokumenty/Komentarze/ autorprognieo.pdf

Krawiec, F. (Ed.). (2010). Odnawialne źródła energii $w$ świetle globalnego kryzysu energetycznego. Wybrane problemy [Renewable energy sources in the context of the global energy crisis. Selected Problems].Warszawa: Difin.

Kuś, J., \& Faber, A. (2007). Alternatywne kierunki produkcji rolniczej [Alternative trends of agricultural production] (Studia i Raporty IUNG-PIB No 7, pp. 139-149). Instytut Uprawy Nawożenia i Gleboznawstwa, Państwowy Instytut Badawczy, Puławy.

Kuś, J., \& Faber A. (2009). Produkcja roślinna na cele energetyczne a racjonalne wykorzystanie rolniczej przestrzeni produkcyjnej Polski. Przyszłość sektora rolno-spożywczego i obszarów wiejskich [Crop production for energy and the rational use of Polish agricultural production. The future of the agri-food sector and rural areas]. Paper presented at I Kongres Nauk Rolniczych May 14-15, 2009, Puławy Retrieved from http://www.cdr.gov.pl/kongres1/ files/1.3.1.pdf
Majewska-Sawka, A. (2009). Miskant olbrzymi [Miscanthus giganteus]. Czysta Energia, 11(99), 34-35.

Michałowska - Knap, K., Włodarski, M., Dietrich, D. (2010). Zagadnienia wykorzystania odnawialnych źródeł energii w regionach - analiza porównawcza [Issues of renewable energy sources in the regions a comparative analysis]. Instytut Energii Odnawialnej. Retrieved from http://www.gab.com.pl/ strony/ef2007/prezentacje/3.pps\#610

Minister Gospodarki. (2010). Krajowy plan działania $w$ zakresie energii ze źródeł odnawialnych (Projekt) [The national action plan for energy from renewable sources (Project)]. Warszawa: Ministerstwo Gospodarki.

Ministerstwo Gospodarki. (2009). Polityka energetyczna Polski do 2030 roku [Polish Energy Policy until 2030]. Załącznik do uchwały nr 202/2009 Rady Ministrów. Dokument przyjęty przez Radę Ministrów w dniu 10 listopada 2009 roku [Annex to Resolution No. 202/2009 of the Council of Ministers. The document was adopted by the Council of Ministers on 10 November 2009] Warszawa: Ministerstwo Gospodarki.

Rada Ministrów (2007). Rozporządzenie Rady Ministrów z dnia 15 czerwca 2007 r. $\quad$ w sprawie Narodowych Celów Wskaźnikowych na lata 2008-2013, Dz. U. Nr 110, poz. 757. [Regulation of Ministers of the Council of 15 June 2007 on the National Indicative Targets for 2008-2013 ].

Sørensen, B. A. (2008). A sustainable energy future: Construction of demand and renewable energy supply scenarios. International Journal of Energy Research [Special issue on Renewables and Hydrogen Energy Technologies for Sustainable Development], 32(5), 436-470.

Tollefson, J. (2009). Copenhagen: the scientists' view. Nature, 462(7274), 714-715.

Totlandsdal, A. I., Fudge, N., Sanderson, E. G., van Bree L., \& Brunekreef B. (2007). Strengthening the science-policy interface: experiences from a European Thematic Network on Air Pollution and Health (AIRNET). Environmental Science \& Policy, 10 (3), 260-266.

van Velthuizen, H. (2003). Agro-ecological zoning of Europe. Paper presented at IRENA Workshop on Land-use/cover change, Landscape state and characterization of rural areas. Joint Research Centre 
- European Commision. June 23-24, 2003, Ispra, Italy. Retrieved from: http://agrienv.jrc.it/activities/pdfs/irena/Velthuizen-AEZ-Europe.pdf

Wiesenthal, T., Mourelatou, A., Petersen, J-E., Taylor, P. (2006). How much bioenergy can Europe produce without harming environment. Luxembourg: Office for Official Publications of the European Communities.

Zegada-Lizarazu, W., Elbersen, H. W., Cosentino, S. L., Zatta, A., Alexopoulou, E. \& Monti A. (2010). Agronomic aspects of future energy crops in Europe. Biofuels, Bioproducts and Biorefining [Special Issue: Biofuels for Europe[, 4(6), 674-691.

\section{Notes}

1. Incidentally, communication problems between governments and scientists are not new. According to Abelson (1988), relations between politicians and the scientific community depend on the proprieties of a given country and the needs of the government. For example, in the USA, the importance of scientific issues in political programs has changed significantly since the 1950's, when the A-bomb was the most important problem. It may be assumed that at that time, scientists were still in control of that issue. However, since that time, science has come to be perceived as complementary to politics insofar as it can be used to gain support for political objectives.

2. The paper is financed by funds of the European Fund for Regional Development within the framework of the Operation Program "Innovative Economy," 2007-2013, as a research project on the "Development of a species index and optimization of production technology for selected energy crops", no. POIG.01.03.01-00-132/08-00.

3. Assumptions for the forecast: cereal yield 3 ton/ ha; 3 tons of cereals are needed to produce 1 ton of bioethanol. To produce 1 ton of bioethanol, 3.3 tons of molasses are needed. In Poland, approximately 0.5 million tons of molasses are produced annually, of which 80 - 150 thousand tons have been used to produce bioethanol in recent years. For calculations, molasses utilization of approximately 150 thousand tons annually is assumed. It was further assumed that from $1 \mathrm{~kg}$ of rapeseed, $0.4 \mathrm{~kg}$ of biodiesel is produced. For 2010, the yield of rapeseed was assumed to be $3 \mathrm{t} / \mathrm{ha}$; in $2017-2018,3.1 \mathrm{t} / \mathrm{ha}$; and in 20192020, $3.3 \mathrm{t} / \mathrm{ha}$.

4. According to studies by the Institute of Construction, Mechanisation and Electrification of Agriculture IBMER (currently the Institute of Technology and Life Sciences [ITP]), the mean annual excess harvested straw above utilization-i.e., straw that could have been used in the power industry-amounts to 11.5 million tons in Poland. Studies conducted by IUNG are much more conservative, indicating that only approximately 3 - 4 million tons of straw may realistically be allocated for energy purposes.

5. See http://www.pigeo.org.pl/index.php?a=10002 \&id_ $a=43$. 